\title{
ANALISIS PROSES PERENCANAAN PEMBELAJARAN PENDIDIKAN KESETARAAN PAKET B BERBASIS KURIKULUM 2013 DI SANGGAR KEGIATAN BELAJAR (SKB) KOTA SAMARINDA
}

\author{
Titra Weni \\ Program Studi Pendidikan Masyarakat, Universitas Mulawarman \\ Email: titraweni8@gmail.com
}

\begin{abstract}
Equivalent education package $B$ based on the 2013 curriculum is a non-school education program that is equivalent to formal junior high school education. The delivery of education is carried out by following the curriculum that should be the 2013 curriculum and is expected to answer solutions for people who drop out of school or who need education. This study aims to find out how Equivalent Education Learning Package B based on 2013 Curriculum and what factors influence the learning process. This research was conducted at the Samarinda City Learning Activity Center specifically the Package B program. Data collection in this study using interview, observation, and documentation techniques. The results of the study showed that the implementation of equality education package B based on the 2013 curriculum in Samarinda City SKB consisted of three stages, namely planning, implementation, and assessment of learning and factors influencing the learning outcomes of citizens learning package B. by developing learning tools that will be used for learning, that is, compiling lesson plans and syllabi that are adapted to the equality education module package B curriculum 2013 and recruiting citizens to learn by open and individual socialization.
\end{abstract}

Keywords: learning, equality education, 2013 curriculum, learning planning

\section{PENDAHULUAN}

Pendidikan nasional pada dasarnya dimaksudkan untuk mencerdaskan kehidupan bangsa secara berkelanjutan. Tertuang dalam UU No. 20 Tahun 2003 menyatakan bahwa pendidikan nasional berfungsi mengembangkan kemampuan dan membentuk watak serta peradaban bangsa yang bermartabat dalam rangka mencerdaskan kehidupan bangsa dengan bertujuan mengembangkan potensi peserta didik agar menjadi manusia yang beriman dan bertaqwa kepada Tuhan Yang Maha Esa, berakhlak mulia, sehat, berilmu, cakap, kreatif, mandiri dan menjadi warga negara yang demokratis serta bertanggung jawab. 
Peningkatan mutu pendidikan sebagaimana ditekankan dalam misi pendidikan nasional diharapkan bisa menjawab tantangan yang dihadapi dalam hal pemenuhan kebutuhan pendidikan berkualitas bagi setiap masyarakat. Hal itu perlu adanya penyelenggaraan pendidikan, salah satunya adalah pendidikan Nonformal yang diatur dalamUndang-undang Nomor 20 Tahun 2003 tentang Sistem Pendidikan Nasional menyatakan bahwa Pendidikan Nonformal berfungsi mengembangkan potensi peserta didik dengan penekanan pada penguasaan pengetahuan dan keterampilan fungsional serta pengembangan sikap dan kepribadian profesional".

Pada prakteknya penyelenggaraan pendidikan nonformal dilaksanakan untuk mencapai tujuan pendidikan nasional melalui beberapa program. Salah satunya adalah program pendidikan kesetaraan. Pendidikan kesetaraan adalah program pendidikan nonformal yang menyelenggarakan pendidikan umum setara SD/MI, SMP/MTs, dan SMA/MA yang mencakup program paket A, paket $B$, dan Paket C. Penyelenggaraan pendidikan kesetaraan merupakan bagian yang tidak terpisahkan dari pelaksanaan pendidikan nasional yang secara khusus dimaksudkan untuk mencapai tujuan pendidikan. Pada penyelenggaraan pndidikan dibutuhkan kurikulum sebagai salah satu hal penting pada pelaksanaan pendidikan.

Kurikulum pendidikan kesetaraan dikembangkan mengacu dan melalui kontekstualisasi kurikulum pendidikan formal mencakup pengetahuan, keterampilan, dan sikap serta disesuaikan dengan masalah, kebutuhan dan karakteristik pendidikan kesetaraan. Lulusan pendidikan ini diharapkan dapat mengisi ketersediaan ruang publik di masyarakat dengan berbagai aktifivitas sosial, ekonomi, dan budaya secara kreatif dan inovatif sehingga pendidikan ini bukan hanya sebagai pendidikan alternatif, tetapi untuk meningkatkan kualitas hidup dan mendorong perkembangan kemajuan masyarakat.

Kontekstualisasi kurikulum 2013 pendidikan kesetaraan digunakan sebagai dasar untuk menyusun silabus dan Rencana Pelaksanaan Pembelajaran (RPP) dengan memperhatikan karakteristik pembelajaran kesetaraan, yaitu menggunakan pendekatan tematik, fungsional, kontekstual, berbasis kebutuhan dan perkembangan usia peserta didik. Karakteristik pembelajaran orang dewasa dan menerapkan strategi pembelajaran melalui tatap muka, tutorial dan belajar mandiri secara terpadu. Pelaksanaan pembelajaran pada pendidikan kesetaraan akan berjalan dengan jika dilaksanakan kegiatan perencanaan pembelajaran. Bararah (2017) mengungkapkan bahwa Perencanaan teramat dibutuhkan sebelum pelaksanaan proses pembelajaran dilaksanakan, hal ini diperuntukkan agar proses pembelajaran tersusun dan terarah sesuai dengan tujuan pembelajaran yang akan dicapai dalam sebuah satuan pendidikan. Berdasarkan hal tersebut maka 
perencanaan pembelajaran khususnya pada pembelajaran di pendidikan kesetaraan menjadi hal yang sangat penting.

Hasil kajian pendahuluan mengungkapkan bahwa penerapan pendidikan kesetaraan berbasis kurikulum 2013 salah satunya dilaksanakan di Sanggar Kegiatan Belajar (SKB) Kota Samarinda sebab penerapan kurikulum 2013 ini wajib dilaksanakan oleh satuan pendidikan nonformal. Selain itu Sanggar Kegiatan Belajar (SKB) Kota Samarinda dijadikan sebagai percontohan kegiatan pendidikan luar sekolah. Berdasarkan hal tersebut maka peneliti ingin mengkaji lebih mendalam tentang Analisis Perencanaan Pembelajaran Pendidikan Kesetaraan Paket B Berbasis Kurikulum 2013 di Sanggar Kegiatan Belajar (SKB) Kota Samarinda. Tujuan penelitian ini adalah untuk menganalisis bagaimana proses perencanaan pembelajaran yang ada pada pendidikan kesetaraan di Sanggar Kegiatan Belajar (SKB) Kota Samarinda.

\section{METODE PENELITIAN}

Jenis penelitian yang akan digunakan dalam penelitian ini adalah metode deskriftif kualitatif. Penelitian yang akan dilaksanakan akan memperoleh data. Moleong dalam Margono (2014: 36) menerangkan bahwa penelitian kualitatif adalah prosedur penelitian yang menghasilkan data deskriptif berupa kata-kata tertulis atau lisan dari orang-orang dan prilaku yang dapat diamati. Teknik pengumpulan data yang digunakan disini adalah cara atau metode yang dapat digunakan oleh peneliti untuk mengumpulkan data, sehingga benar-benar data yang didapatkan valid dan relevan. Teknik pengumpulan data yang dikemukan oleh Sugiyono (2017: 309) terdapat tiga macam teknik pengumpulan data:

1. Observasi, data dikumpul dan seiring dengan bantuan berbagai alat yang sangat canggih, sehingga benda-benda yang sangat kecil maupun yang sangat jauh dapat diobservasi dengan jelas. Observasi Partisipasi pasif (passive participation). Dalam observasi ini peneliti datang di tempat kegiatan orang yang diamati, tetapi tidak ikut terlibat dalam kegiatan tersebut.

2. Wawancara. Esterberg dalam Sugiyono (2017: 317) mendefinisikan wawancara adalah merupakan pertemuan dua orang untuk bertukar informasi dan ide melalui tanya jawab, sehingga dapat dikonstruksikan makna dalam suatu topik tertentu. Proses untuk mendapatkan data penelitian ini peneliti akan menggunakan wawancara dimana peneliti sudah mempersiapkan pertanyaan yang akan ditanyakan kepada informan secara terstruktur ini bertujuan agar peneliti memperoleh data dengan lengkap dan detail terlebih tersusun memudahkan peneliti mengolah data yang diterima. Sasaran yang akan diwawancara menggunakan teknik ini adalah kepala SKB Kota Samarinda, tutor paket B, dan warga belajar paket B. Wawancara yang akan dilaksanakan untuk memperoleh data ada dua cara yaitu pertama bertemu langsung dengan 
informannya di tempat lokasi penelitian, kedua wawancara melalui via whatsapp (online).

3. Studi Dokumentasi. Studi dokumentasi merupakan catatan peristiwa yang sudah berlalu. Maleong dalam Sedarmayanti \& Hidayat (2011:34) studi dokumentasi adalah catatan tertulis yang isinya merupakan setiap pernyataan tertulis yang disusun oleh seseorang atau lembaga untuk keperluan pengujian atau suatu peristiwa atau menyajikan akunting dan berguna bagi sumber data, bukti, informasi. Studi dokumentasi merupakan pelengkap dari penggunaan metode observasi dan wawancara dalam penelitian kualitatif. Bahan dokumenter dalam penelitian kualitatif dapat berupa dokumen pribadi seperti catatan atau karangan seseorang secara tertulis dalam bertindak, pengalaman, yang bentuknya berupa buku harian, surat pribadi, otobiografi, bukti, foto, slide, mikro film, film dan dokumen resmi seperti memo, pengumuman, instruksi, aturan suatu lembaga, majalah, dan buletin (Sedarmayanti dan Hidayat 2011: 35).

\section{HASIL DAN PEMBAHASAN}

\section{Perencanaan Pembelajaran}

Perencanaan pembelajaran kurikulum 2013 dilaksanakan pada pelaksanaan pembelajaran di pendidikan kesetaraan. Perencanaan pembelajaran ini dilaksanakan untuk mempersiapkan kegiatan pendidikan kesetaraan. Perencanaan pembelajaran dilaksanakan melalui kegiatan-kegiatan persiapan pembelajaran. Mustangin (2020) Adanya perencanaan program pendidikan maka akan memudahkan pelaksana program pendidikan untuk melaksanakan program pendidikan nonformal tersebut, Sehingga perencanaan program pada pendidikan nonformal menjadi sangat penting untuk mendapatkan hasil yang maksimal. Berdasarkan hal tersebut maka perencanaan pada kegiatan pendidikan salah menjadi penting termasuk dalam proses pembelajarannya sebagai bagian dari kegiatan pendidikan.

\section{Penyusunan program tahunan dan semesteran}

Perencanaan pembelajaran pendidikan kesetaraan Paket B dilakukan pihak lembaga agar kegiatan ini dapat berjalan dengan tertib yaitu membuat program dalam jangka pendek maupun panjang agar pelaksanaan pembelajaran kesetaraan Paket B berbasis kurikulum 2013 berjalan dengan terarah dan memiliki tujuan. Julhaidi dan Nurahman (2019) Dalam Kurikulum 2013 atau sering disebut K13 guru diwajibkan membuat PROTA (Program Tahunan), PROSEM (Program Semester). Program semester merupakan penjabaran dari program tahunan. Dalam melakukan proses pembelajaran warga belajar harus bisa membuat program tahunan dan program semester, karena merupakan pedoman bagi pengembangan program-program berikutnya. 


\section{Penyiapan Rencana Pelaksanaan Pembelajaran (RPP)}

Proses perencanaan pembelajaran berbasis kurikulum 2013 yang telah dilaksanakan oleh SKB Samarinda dimulai dari menyusun program tahunan dan program semesteran serta menyusun perangkat pembelajaran yang akan digunakan untuk pembelajaran. Salah satunya adalah menyusun RPP dan Silabus yang disesuaikan dengan Modul Kesetaraan Paket B berbasis Kurikulum 2013.

Sebelum mengajar tutor akan menyusun RPP dari modul dan silabus pendidikan kesetaraan paket B kurikulum 2013 yang diperoleh melalui web sumberbelajarseamolec sehingga tutor dapat terlebih dahulu menguasai dan memahami materi yang akan disampaikan dikelas. Susetya (2017) mengungkapkan bahwa Perencanaan pembelajaran dituangkan ke dalam Rencana Pelaksanaan Pembelajaran (RPP) atau beberapa istilah lain seperti desain pembelajaran, skenario pembelajaran. RPP memuat KI, KD, indikator yang akan dicapai, materi yang akan dipelajari, langkah pembelajaran, media pembelajaran, dan sumber belajar serta penilaian. Hal ini dimaksudkan untuk mempermudah dalam melaksanakan kegiatan pembelajaran. Hal tersebut juga dapat memudahkan tutor dalam mengajar karena perangkat pembelajarannya sudah dipersiapkan sebelum memulai melaksanakan pembelajaran.

\section{Penentuan Metode Pembelajaran}

Proses penyusunan RPP akan membawa tutor mempersiapkan metode pembelajaran. Hal ini sesuai dengan pendapat Suyono dan Hariyanto (2015: 92) mengatakan bahwa penerapan metode pembelajaran juga bergantung kepada ciri bahan ajar dan waktu dialokasikan dalam Rencana Pelaksanaan Pembelajaran (RPP).

Metode pembelajaran yang dipersiapkan oleh tutor untuk mempermudah melaksanakan pembelajaran yang sedang berlangsung dikelas dan mencapai tujuan pembelajaran. Uno dan Nurdin (2011: 7) mendefinisikan metode pembelajaran sebagai cara yang digunakan guru dalam menjalankan fungsinya dan merupakan alat untuk mencapai tujuan pembelajaran.

Pada penyusunan RPP tutor akan mempersiapkan metode pembelajaran yang sesuai dengan materi. Berkaitan dengan itu akan memudahkan tutor melaksanakan prosedur pembelajaran berdasarkan langkah-langkah kegiatan pembelajaran sehingga tutor dengan mudah menyampaikan materi dengan jelas dan detail. 


\section{Rekrutmen Warga Belajar}

Proses selanjutnya adalah proses rekrutmen warga belajar. Tahap ini berlangsung setelah pihak penyelenggara sudah siap untuk melaksanakan pembelajaran karena tanpa warga belajar kegiatan pembelajaran tidak akan berjalan. Hal ini diungkapkan oleh Badrudin (2014: 32) mengenai rekrut warga belajar yaitu, rekrutmen peserta didik yang nantinya menjadi peserta didik di lembaga pendidikan tersebut.

Langkah untuk mendapatkan warga belajar di SKB adalah melalui sosialisasi cukup melakukan hal ini jika ada warga belajar yang mendaftar dan memenuhi persyaratan maka warga belajar tersebut akan diterima. Strategi ini adalah sama seperti promosi yang diungkapkan oleh Imron (2015) bahwa penerimaan peserta didik yang sebelumnya tanpa menggunakan seleksi. Mereka yang mendaftar sebagai peserta didik disuatu sekolah diterima semua begitu saja. Karena itu, mereka yang didaftar tidak ada yang ditolak.

Sasaran untuk mendapatkan warga belajar adalah masyarakat maupun instansi yang memerlukan pendidikan kesetaraan paket B. Sebagaimana ketentuan umum Undang-undang RI No. 20 Tahun 2003 tentang Sistem Pendidikan Nasional adalah anggota masyarakat yang berusaha mengembangkan potensi diri melalui proses pembelajaran yang tersedia pada jalur, jenjang, dan jenis pendidikan tertentu.

Proses rekrutmen adalah proses untuk mencari dan mendapatkan warga belajar yang memerlukan pendidikan. Dilakukan oleh pihak penyelenggara dengan strategi promosi atau sosialisasi, cara ini mempermudah masyarakat sebagai sasaran sosialisasi ini untuk mendapatkan informasi mengenai penyelenggaraan pendidikan keseteraan paket $\mathrm{B}$.

\section{SIMPULAN}

Proses perencanaan pembelajaran yaitu dimulai dengan menyusun perangkat pembelajaran seperti RPP, dan silabus. Hal ini dimaksudkan untuk mempermudah dalam melaksanakan kegiatan pembelajaran. Pada penyusunan RPP tutor akan mempersiapkan metode pembelajaran yang sesuai dengan materi. Berkaitan dengan itu akan memudahkan tutor melaksanakan prosedur pembelajaran berdasarkan langkah-langkah kegiatan pembelajaran sehingga tutor dengan mudah menyampaikan materi dengan jelas dan detail. Susunan RPP yang disusun berdasarkan Kurikulum 2013 dibuat oleh tutor paket B SKB Kota Samarinda disusun dengan Standar Isi yakni semua mata pelajaran terikat satu sama lain dan mendukung kompetensi inti dan langkah pembelajaran meliputi mengamati, menanya, menalar, mencoba, dan membentuk jaringan. Terakhir adalah rekrutmen warga belajar adalah proses untuk mencari dan mendapatkan warga belajar yang memerlukan pendidikan. Dilakukan oleh pihak penyelenggara 
dengan strategi promosi atau sosialisasi, cara ini mempermudah masyarakat sebagai sasaran sosialisasi ini untuk mendapatkan informasi mengenai penyelenggaraan pendidikan keseteraan paket $\mathrm{B}$.

\section{DAFTAR PUSTAKA}

Badrudin 2014. Manajemen Peserta Didik. Jakarta: Indeks

Bararah, I. (2017). Efektifitas Perencanaan Pembelajaran dalam Pembelajaran Pendidikan Agama Islam di Sekolah. Jurnal Mudarisuna: Media Kajian Pendidikan Islam. Vol 7 (1): 131-147

Julhaidi, A \& Nurahman. (2019). Penerapan Perangkat Pembelajaran k13 Berbasis Web. Inform : Jurnal Ilmiah Bidang Teknologi Informasi dan Komunikasi Vol. 4 (2)

Imron, Ali. 2015. Manajemen Peserta Didik Berbasis Sekolah, Jakarta: Bumi Aksara.

Mustangin. 2020. Analisis Proses Perencanaan Program Pendidikan Nonformal Bagi Anak Jalanan Di Klinik Jalanan Samarinda. Pepatuzdu: Media Pendidikan Dan Sosial Kemasyarakatan. Vol 16. (1): 1-9

Sedarmayanti dan Hidayat, Syarifudin. 2011. Metodologi Penelitian. Bandung: Mandar Maju.

Sugiyono. 2017. b. Metode Penelitian Pendidikan Pendekatan Kuantitatif, Kualitatif, dan R\&D. Bandung: Alfabeta.

Susetya, B. (2017). Meningkatkan Kemampuan Guru Dalam Menyusun Silabus Dan Rpp Melalui Supervisi Akademik Di Sd N Gambiran Yogyakarta Tahun 2016. Jurnal Taman Cendekia Vol. 01 (02): 134-141

Suyono \& Hariyanto. 2015. Implementasi Belajar \& Pembelajaran. Bandung: Remaja Rosdakarya.

Undang-Undang RI Indonesia Nomor 20 Tahun 2003 Tentang Sistem Pendidikan Nasional Pasal 26 ayat 2.

Uno, B Hamzah, \& Nurdin, Muhamad . 2011. Belajar dengan Pendekatan PAILKEM. Jakarta : Bumi Aksara 